\title{
Effect of recruitment of new MUs on mechanomyographic signal during prolonged isometric constant contractions at low level
}

\author{
Shigeru Morimoto ${ }^{1}$ and Mifuyu Kamo ${ }^{2}$ \\ ${ }^{1}$ 横浜国立大学教育人間科学部学校教育課程保健体育講座， ₹ 240-8501 神奈川県横浜市保土ヶ谷区常盤台 79-2 (Faculty \\ of Education and Human Sciences, Yokohama National University, 79-2 Tokiwadai, Hodogaya-ku, Yokohama, Kanaga- \\ wa 240-8501, Japan) \\ ${ }^{2}$ 日本女子体育大学体育学部， ₹ 157-8565 東京都世田谷区北烏山8-19-1 (Faculty of Physical Education, Japan Women's \\ College of Physical Education, 8-19-1 Kitakarasuyama, Setagaya, Tokyo 157-8565, Japan)
}

Received: September 24, 2012 / Accepted: February 7, 2013

\begin{abstract}
The present study focused on the effect of the newly motor unit (MU) recruitment on mechanomyographic signal (MMG) by the analysis on motor unit mechanical signal (MUMS) during prolonged isometric constant contraction (PICC) at low torque levels of the knee extension. The mechanical and myoelectric signals (MES) from m. vastus medialis or lateralis were recorded by condenser microphone and disc electrode, respectively. In order to recruit the objective MU during the PICC, the target torque set at several levels below the recruitment threshold torque of the MU ( $\leqq 7.4 \% \mathrm{MVC})$. 1) iMMG and iMES sustained constant for initial several minutes and then increased during the PICC. 2) MUMS superimposed on MMG from back ground MUs activities and iMUMS increased significantly at the timing of MU recruitment. Subsequent iMUMS decreased according to the decrement of MUMS amplitude depend on the discharge trend of the MU. 3) Amplitude of MUMS (MS- $\mathrm{V}_{\text {positive }}$ ) showed different trend depended the recruitment timing during PICC. At the iMMG constant phase, MS- $V_{\text {positive }}$ sustained constant followed by the increment similar to iMMG trend. In contrast, at iMMG increment phase, $M S-V_{\text {positive }}$ showed increment trend without the constant phase. The present results suggested that the newly MU recruitment increase the iMMG during the PICC. IMMG increment at later period of the PICC could interpret from the MU recruitment and MS$\mathrm{V}_{\text {positive }}$ increment. It is necessary to investigate the factors to increase the MS- $\mathrm{V}_{\text {positive }}$ from the muscle and muscle fibers conditions.
\end{abstract}

Jpn J Phys Fitness Sports Med, 62(2): 159-169 (2013)

Keywords : motor unit, mechnomyographic signal, recruitment, prolonged activity

\section{緒言}

骨格筋は収縮時に“音”を発生する。この筋音 (mechanomyographic signal: MMG）は骨格筋の収縮状態ある いは運動単位（motor unit: MU）の活動様式を反映する 信号である可能性が示唆されてきている.

骨格筋の収縮状態に着目した時，筋線維束に対する電 気刺激頻度 ${ }^{1,2)}$ とMMG振幅, 随意運動下の運動単位にお いてはその発火頻度 ${ }^{3)}$ と運動単位筋音信号（MUMS: motor unit mechanical signal）は反比例関係にあることが 報告されている。すすわち興奮頻度の増加は筋線維 (群) を単収縮から不完全強縮, 完全強縮へと状態変化をもた らし，筋線維の“動き”が小さくなることから刺激頻度
とMMG振幅の反比例関係を考察している.

Akataki et al. ${ }^{4}$ は，ヒトの随意的最大筋力 (maximal voluntary contraction: MVC) に至るまで全筋（上腕二 頭筋）のMMGを追跡し, 振幅と特徵周波数から解析を 行っている. その結果, MMG振幅, 特徵周波数をMU発 火頻度との関係まで押し広め, MMGからMUの活動参加 と活動MUの発火頻度変化を推定可能と考察している.

低水準筋力（ $\leqq 20 \% \mathrm{MVC} ）$ を一定保持した時，表面 筋電位信号 (myoelectric signal: MES) 積分值 (iMES) は初期に一定值を呈した後, 漸増傾向を示す. 同実験条 件下でMUの放電間隔は初期に延長し，その後短縮する 傾向にある ${ }^{5)}$.さらに, 新しいMUの活動参加, 活動し ていたMUの活動休止（活動交代）が筋力発揮初期より 
観察されている 複雑な MU活動が存在し, それらの結果としてiMESの 変化動態があると考えられる。同様な実験条件下の低い 目標筋力を一定保持した (prolonged isometric constant contraction: PICC）時，ヒトの皮膚表面から導出された MMGの積分值（iMMG）は初期に一定值，その後変局 点を持つように急激な増大を示す。iMMG は IMESとは 異なる増加動態にあり ${ }^{3,7-9)}, \mathrm{MMG}$ にはMESと異なる情 報が内在する可能性が示唆される。いまだ解釈に至らな いiMMG増大傾向が，MUの活動様式または筋収縮状態 の変化に起因するのか，また新しい知見を提示する可能 性が存在するのか，等を検討することは随意的一定筋力 調節機構の解明に示唆を与える可能性とともに, MMG の適用の範囲を探る上で意味あることと考える.

これまでMU活動から提唱されている低水準PICC時 のiMMG増大因子は, MUの同期化活動, 放電間隔変化 および活動参加に存在するとされてきだ7)。しかし，こ の提唱には単一 MUを用いた直接的な観察, 検証が必要 と考えられるが，これまで行われてこなかった，MUの 活動電位 (motor unit action potential: MUAP) と MMG 信号 (motor unit mechanical signal: MUMS) をPICC時 に直接観察した時, 観察対象MUと非特異的に同期化活 動するMUの相対的量変化とMUMS振幅 $\left(\mathrm{MS}-\mathrm{V}_{\text {positive }}\right)^{9}{ }^{9}$, およびMUの放電間隔変化とMS- $\mathrm{V}_{\text {positive }}{ }^{3}$ 間に意味ある 関係性が見出せなかった，MUMSがMMGを構成する基 本波形とした時，MMG増大がMUの同期化活動，放電 間隔変化に依存した現象ではないことが示唆された。次 の観点として, MMG増大の解釈にMU活動参加からの 評価を行う必要がある.MESの増大は悉無律に従った MUAPの加重から推定可能であるが, MUMSは悉無律 に従った反応を示さないため ${ }^{1-3)}, \mathrm{MES}$ 増大とは異なる MMG増大の仕組みを構築する必要性が示唆される。振 動の音圧の加重からMMG増大に貢献はするが，放電間 隔依存性からMUの活動参加時点とその後の放電期間で はMMG増大の影響程度が異なることが推察される。こ れに対し，随意的にMU放電間隔を一定調節したPICC後 半でiMESが一定值をとったにも関わらずiMMGは持続 的に増大した結果から ${ }^{3)}, \mathrm{MMG}$ はMU活動参加に影響を 受けないとも推察できる。何れの推察も随意運動下で直 接 MUの活動参加を観察した検証が必要となる.

そこで，本報告ではMMG増大因子としてMUの活動参 加に注目し, 内側広筋（m. vastus medialis: VM）または 外側広筋 (m. vastus lateralis: VL) よりMES, MUAP, MMG 㧍よびMUMSを同時に導出し，PICC中に拈ける MUの活動参加時点とその後におけるiMMG, iMUMS, $M S-V_{\text {positive }}$ の変化動態について観察を行った。観察対象 MUの活動参加闇值張力以下の目標筋力でPICCを実施 し，PICC経過途中でMUの活動参加を発現させる事を試

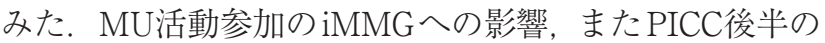
$\mathrm{iMMG}$ の増大が活動参加から解釈可能か，を検討するこ とに目的を置いた。

\section{方法}

実験実施に先立ち本実験の目的，意義および想定され る危険性について充分な説明を行い，参加に同意の得ら れたものに被験者として実験参加を依頼した。この実験 は横浜国立大学倫理委員会のヘルシンキ宣言に則った審 査で承認を得てから実施した。被験者は神経一筋疾患お よび履歴の無いものであった。

MES, MUAP とMMG, MUMSは 7 名の成人被験者（女 性 1 名, 男性 6 名: 20 59歳, 身長: $172.0 \pm 6.4 \mathrm{~cm}$; 体重： $60.2 \pm 7.5 \mathrm{~kg} ）$ の右 VMまたはVLより導出した。被験者 には，実験実施日 2 日前より，高強度の身体活動は控え

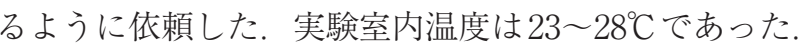

信号の記録 被験者は実験台（高さ $70 \mathrm{~cm} ） に$ 腰かけ， 下腿を下垂した，被験者の腰部はべルトを介して実験台 に固定した．膝関節伸展張力を等尺性に検出するために 実験側足関節部にベルトを固定し、ワイヤーを介してロー ドセル（RTB-100K, 日本光電）に接続した。ロードセル の出力はキャリアーアンプ (6M84, 日本電気三栄; lowpass filter $100 \mathrm{~Hz}$ ）にて増幅した。股関節と膝関節角度 は90から95度とした。

MMG，MUMS導出にはコンデンサー型マイクロフォ ンを用いた（DMS-011, ダイアメデイカルシステム, bandpass $2-1 \mathrm{kHz}$, 直径 $10 \mathrm{~mm}$, 重量 $9 \mathrm{~g}$ ). MUMS導出マイク ロフォンの装着位置は観察対象 MUの運動終板領域とし, 実験に先立ちMUAP波形の解析から位置の特定を行った (参照: 方法 MUAP再現性導出の同定 ${ }^{9-13)}$. マイクロフォ ンドラムは外部大気との気密性を保つよう両面接着テー プで皮膚表面上に固定した。 マイクロフォンの出力は直 流増幅器（DPA-251S, ダイアメデイカルシステム; 入力 抵抗 $1 \mathrm{M} \Omega$, 出力抵抗 $100 \Omega$ ）に入力し, band-pass filter 1-1 kHzにて増幅した. $M M G$ 導出のマイクロフォンは観 察対象 MUの信号の混入を防ぐために，MU筋線維走行に 対して内側あるいは外側直行方向へMUMS 導出センサー から $30 \mathrm{~mm}$ 程度離れた位置に装着した。

MESおよびMUAP 導出には 3 対の $\mathrm{Ag} / \mathrm{AgCl}$ 血型電極 を用いた（直径 $5 \mathrm{~mm}$ )。2 対はMUAP導出電極とし， 1 対はMES導出電極として用いた，MUAPの導出では，1 対はMUAP双極導出（電極間距離 $10 \mathrm{~mm}$ ）としてMUMS 導出用マイクロフォンセンサー直近の筋線維走行方向に 沿った中枢側に装着した。他の 1 対の電極は単極 MUAP 導出用として用い，七ンサー末梢側に筋線維走行方向に そった任意の位置に 1 対の 1 方（非反転入力電極）を装 着した。残りの 1 対の電極は単極のMES導出用とした. 
$\mathrm{MES}$ 導出の 1 対の 1 方の電極は $\mathrm{MMG}$ 導出マイクロフォ ンの直近，末梢側に装着した，単極導出の場合，他の電 極（反転入力）は膝蓋骨上の皮膚に装着した，導出され た信号は差動増幅器 (入力抵抗 $50 \mathrm{M} \Omega$, 出力抵抗 $100 \Omega$, band-pass filter: 3-10kHz; DPA-401S, ダイアメデイカ ルシステム）にて増幅した。電極間抵抗は $20 \mathrm{k} \Omega$ 以下と なるようにケラチンクリーム（フクダ電子）にて皮膚を 研磨後, 酒精綿にて十分に払拭した。

全ての信号はPCMデータレコーダー (band-pass filter: DC- $5 \mathrm{kHz}$, 入力抵抗 $100 \mathrm{k} \Omega, \mathrm{PC}-208 \mathrm{Ax}$, ソニーマ ニュファクチュアリングシステムズ) に入力し, DATテー プに記録した。

MUAP再現性導出の同定 MUAPの再現性導出は以下 の手順に従って観察対象 MUの運動終板の皮膚上の位置 を特定して行った。

皮膚表面上にて悉無律に従った同波形を呈するMUAP を探り，その皮膚上の位置を油性インクにてマークした (基準電極：双極導出），想定される筋線維の走行方向の 数か所に打いて, 走行方向に直角方向に電極（単極導出） を装着し基準電極の MUAPと同期する最大振幅 MUAP を得られる点をマークし，それら点を線で結び観察する MUAPの筋線維走行方向とした. 次に線上に沿った基準 電極及び 3 か所以上からMUAPを単極導出し, 基準電極 MUAPとの陰性ピーク間の時間差と電極間距離との直線 回帰（相関係数 0.99 以上）からMUAPの伝導速度を算出 した，次に，回帰直線の X-軸接点が $0 \mathrm{~mm}$ になる点, す なわち観察対象MUAPの伝導開始点（運動終板）の位置 を探査した ${ }^{12)}$. 想定される運動終板を挟んで中枢側, 末 梢側に各一対の電極 (双極導出法)にてMUAPを導出し た. 双極導出電極の非反転増幅側へ入力する電極は常に 中枢側とした時, 運動終板をはさんで導出される MUAP 波形は極性が反対となる ${ }^{13)}$. 差動増幅を利用しているた め, 双極導出電極を運動終板が電極間中央に位置するよ うに装着した時, MUAPの運動終板からの両側伝導とそ れぞれの電極でのMUAP波形の逆極性により波形はキャ ンセルされ消失する，この双極電極の中央が運動終板の 位置となる、筋線維部分（運動終板と筋一腱移行部を除 いた部分）から導出したMUAP波形と比較した時（参 照: Figs. 1, 2, 3 inset), 運動終板上から単極導出した MUAPは興奮が電極直下から発生するため第 1 陽性相が なく急峻な立ち上がりを示す。ささらに, この立ち上がり 時点は筋線維部分でのMUAP第 1 陽性相の立ち上がり時 点と一致する ${ }^{13)}$. この点をマークし, 位置の同定の再現 性を確認し, MUAP再現性導出の基準位置とした。ささら にMUの活動参加闇值の $200 \%$ 程度の張力発揮時にも他 のMUAPの干渉が少なく波形の同一性を十分同定可能な MUAP（MU）を観察対象とした（参照：Fig. 1).
実験手順 被験者には，実験装置・実験試行・環境に慣 れること，また表面電極による MU活動電位導出位置の 特定を目的とした実験準備期間を設定した。

観察対象MUのMUAP, MUMS導出用電極扔よびセ ンサー, MES, MMG 導出用電極掞よびセンサー装着, 随意的最大筋力 (maximal voluntary contraction: MVC) 測定の後 5 分以上の休息を入れ，以下に示す課題を順に 行うように依頼した。

課題 1 観察対象MUの活動参加閥値張力の測定 観察 対象のMUの活動参加間值張力を, 筋力発揮勾配 $10 \mathrm{~N} \cdot \mathrm{s}^{-1}$ にて求めた. 15秒間隔で10回実施し, その平均值を $\mathrm{MU}$ の活動参加闇值とした (cf. Fig. 1). 本課題のデー夕は DATテープに保存すると同時に熱ペン式レコーダ（thermal array recorder, RTA-1200, 日本光電) に記録し観察 対象MUの活動参加閾值をただちに計測した。

課題 2 観察対象MUの活動参加閾值以下の目標筋力で のPICC 被験者は約 $10 \mathrm{~N} \cdot \mathrm{s}^{-1}$ の筋力発揮勾配にて目標筋 力まで筋力発揮を行い, その後目標筋力を一定保持した. 目標筋力の設定は, 観察するMUの活動参加闇值張力以 下とした，観察対象MUについて，2 種以上の目標筋力 を設定した。すなわち， PICC 時早期に活動参加する場 合とPICC後半で活動参加する場合の比較を目的とし, 活 動参加閾值未満直近とそれ以下の任意の目標笳力を設定 した．筋力発揮持続時間は10分間とした. 各目標筋力で の試行は実験日を変えて行った。

観察対象のMUAP波形と同時に目標筋力と発揮筋力 を被験者の目前（約 $1 \mathrm{~m} ）$ に設置したブラウン管に表示 し, 被験者への視覚的フィードバックおよび験者への信 号モニターとした。

データ処理・解析 DATテープに保存された信号はA/ $\mathrm{D}$ 変換器 $[ \pm 2.5 \mathrm{~V}$ 入力範囲 $\cdot 16$ - bit分解能; $\mathrm{AD}-12-16 \mathrm{U}$ (PCI), コンテック]を介してサンプリング周波数 $2.5 \mathrm{kHz}$ でデスクトップコンピュータに入力した。データ解析は ソフトウェア (BIMUTAS-II, キッセイコムテック) を 用いて行った。

PICC 時, 発揮筋力が目標筋力に到達した時点より 1 秒後から11秒までの10秒間のデー夕を時間 0 秒時のデー 夕とし, その後 30 秒毎10秒間のデータを解析データとし た。また, 観察対象MUの活動参加時点から前後 3 秒程 度のデータを抽出し，解析データとした。

双極導出MUAPと筋力信号以外のすべての信号から 積分值を求めた。全波整流後, 区間 $100 \mathrm{~ms}$ で積分を行っ た. 30秒毎の解析データは10秒間の平均值として表した。 また, MU活動参加時点の解析デー夕は活動参加時点を 基準とし，1秒毎の区間（division: cf. Figs. 2 \& 3) を 設定し, $100 \mathrm{~ms}$ 積分值と 1 秒毎の $100 \mathrm{~ms}$ 積分值平均値を 求めた。 
双極導出したMUAPは，MU放電間隔の計測を行うと ともに, MUMS 原波形を加算平均するためのトリガー パルスとして用いた. MUMS加算波形を 30 秒毎の10秒 解析区間毎に算出した。算出したMUMS 波形から基線 より陽性相ピークまでの振幅 $\left(\mathrm{MS}-\mathrm{V}_{\text {positive }}\right)^{9)}$ を計測した.

以上の解析を行う前に, MESとMUAPは3-2.5kHz お よびMMGとMUMSは1-500 Hz の band-pass filterにてデ ジタルフィルター処理を行った。

発揮筋力が一定であることを確認するために，発揮筋 力を $50 \mathrm{~Hz}$ の low-pass filter処理した後の信号から, 各解 析区間の 0 秒から 10 秒まで任意の11点の測定を行った. 有意な変動が見られた場合，その試技デー夕は破棄した。

統計処理 PICC時の時間に伴う各変数の差異は一元配 置分散分析で検定を行った，有意性が認められた場合， Scheffeの多重比較を採用した。分散が等しくない場合, Kraskal-Wallis検定を用いた，有意水準は $5 \%$ 以下の危 険率をもって判定した。

\section{結果}

PICC目標筋力設定条件および疲労振戦の出現を避ける 条件から, 結果に示したMUの活動参加閾值張力は $3.7 \%$ MVCから 7.4\%MVCの範囲となった。被験者のMVCは $320 \mathrm{~N}$ から $550 \mathrm{~N}$ の範囲であった。

Fig. 1 にVMから導出した任意のMUにおける活動参 加閾值測定試技時の全ての信号を，また，観察対象MU のMUAP波形を活動参加時点の 1 スパイクおよび初期 10 スパイクの重ね合わせた波形でinsetに示した。活動 参加閾值張力の $200 \%$ 張力程度まで他の MUAPの干渉が 小さく，波形の同定，信号処理の可能なものを観察対象 のMU（MUAP）として採用した。

PICC 時の各信号積分値の変化動態 VLから導出した各 信号について, PICC中のiMES, iMUAP, MU放電間隔, 発揮筋力 (Fig. 2A) およびiMUMS, iMMG（B）の変 化動態の 1 例を示した。VLから導出したMUの活動参

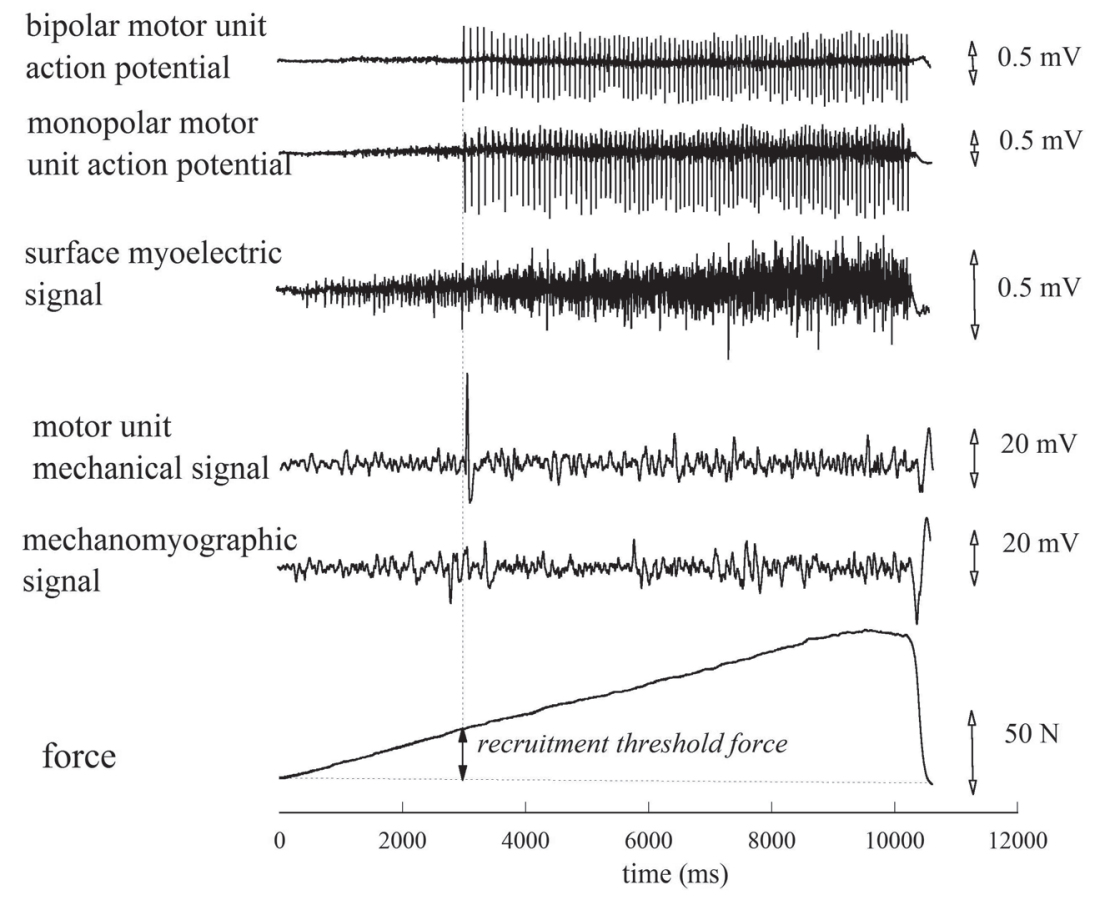

Bipolar MUAP waveform at recruiting timing

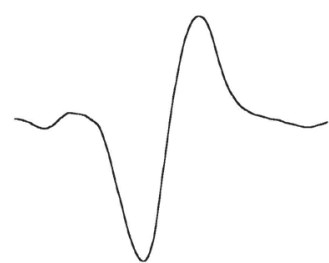

Superimposed MUAP waveform for 10 spikes from recruitment

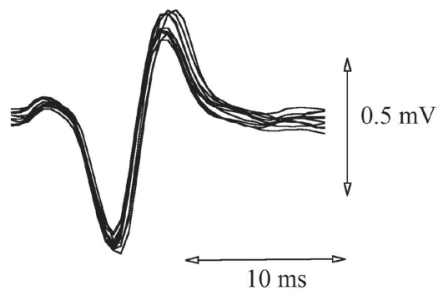

Fig. 1 Typical signals employed in the present study during ramp force tracking at $10 \mathrm{~N} \cdot \mathrm{s}^{-1}$ to $100 \mathrm{~N}$. For technical reason, the signals in this figure were gathered at a sampling rate of $500 \mathrm{~Hz}$, except of the insets $(2 \mathrm{KHz})$. MUAP of the representative MU could discriminate the wave form till $100 \mathrm{~N}$ without interference from other MUAPs. All MU investigated in the present study must be allowed the condition that, at least, MUAP wave form was discriminable up to $200 \%$ of its recruitment threshold force. Recruitment threshold of representative MU was recruited at $34 \mathrm{~N}$ (arrow at force trace). Inset: Bipolar MUAP wave form at recruitment timing shown enlargement of time and amplitude scales (left figure). Right figure showed the superimposed MUAP wave form for 10 spikes from the recruitment. 
加闇值張力は $30.5 \mathrm{~N} ゙$ あった。目標筋力を $22.5 \mathrm{~N} に$ 設定 した時, 観察対象MUは331秒で活動参加した. PICC初 期より iMUAP とiMUMSは任意の值を取り，これは観 察対象の MU以外で背景活動する MUAP, MUMSが構成 するMES，MMGの積分值を意味する，MU活動参加後は MUAP, MUMSが各々MES, MMGに重畳した信号の積 分值iMUAP, iMUMSとなる. 観察対象MUは活動参加後, 10分の筋力発揮終了まで持続的に活動した.

iMES, iMMGはPICC初期に一定值をとり，その後増 大する傾向にあった，しかし，0秒值に比して有意な増 大を示す時間，またその時間值に対して有意な増加を示 す時間に信号間で差異が見られた。iMESは270秒值で有 意な増加となり，その後450秒值で270秒值に対して有意 な高值となり，漸増傾向を示した，iMMGは450秒值で 有意な高值となり，その後 540 秒值で 450 秒值に対して有 意な高值を示した。

PICC初期の iMUMSは一定值をとり, iMMG と同様な 傾向にあった。観察対象 MUが活動参加した330秒区間 でiMUMSは 0 秒值に対して有意な高值を示した。その 後一定值を示したが，570秒で330秒值と比較して有意 な高值となり，増加傾向にあることが示された，以上の 信号積分值に対して, iMUAPは活動参加時点（330秒值） で 0 秒值に対して有意な高值となり, その後PICC終了 時まで統計上に有意な変化動態は見られなかった。

iMUMSの変化動態に注目した時 (Fig. 2B), 活動参加 前の一定値を示す相（前活動参加相）, 観察対象MUの活 動参加に伴う積分值の増大とその後の一定值の相（活動 参加相), 招よび後半部にみられる増大相（後半部増大 相）,の 3 相に便宜的に分けることが出来た，iMMGは有 意な高值を示すまでを一定相，その後を増大相として区 分可能であった.

MUの活動参加時点とその前後のiMUMS Fig. 2 の実 験結果を得た試技から, MU活動参加時点付近 3 秒間の MUAP, MUMS 原波形を抽出しFig. 3 の insetに示した. また同時に, 観察対象のMUAP（双極導出）の波形も示 した. Fig. 3Aは, MU活動参加時点 (1 秒間) と前後 3 秒間（計 7 秒間）につき $100 \mathrm{~ms}$ 区間のiMUMSを，また B は 7 秒間の 1 秒間ごと (division) の $100 \mathrm{~ms}$ 区間iMUMS の平均值を表している. MU活動参加時点でiMUMS平均 值は前 3 divisionに比較し有意な高值となり, その後減少 した，insetに見られるように，iMUMS減少は活動参加 後MUMS の振幅減少と傾向が一致した。 また, 後 3 divisionのiMUMS平均值は前 3 division值に比較し有意な高 值に無かった。

Fig. 4 にVMより導出されたMUについて, Fig. 3 と同 様の解析を行った結果を示した。このMUは $27 \mathrm{~N} の$ 活動 参加闇值張力であった。目標筋力を $22 \mathrm{~N}$ に設定したPICC
において474秒で活動参加した．活動参加時点のiMUMS 平均值は前 3 divisionの值に比較し, 有意な高值をとっ た。また，MUの活動参加後の連続した放電で，積分值 は急減した。しかし, Fig. 3Bの結果と異なり, MU活動 参加後の 3 divisionの積分值は前 3 division との組み合 わせにおいて有意な高值を示した、VMから導出された MUに扔いても, 活動参加時点ではiMUMS は有意な高 值を示す Fig. 3 と同様の結果にあった．以上の結果から, PICC 時の観察対象MU活動参加時点はMMGにMUMSが 重畳し, iMUMSは増大する結果が示された。

\section{$\mathrm{MU}$ 活動参加時点と $\mathrm{iMUMS}, \mathrm{MS}-\mathrm{V}_{\text {positive }}$ 変化動態の差異}

Fig. 5 は, Fig. 4Bに示したMUにて, 目標筋力 $22 \mathrm{~N}$ (A) および25N（B）でPICCを実施した時のiMMG，iMUMS およびMS-V $\mathrm{V}_{\text {positive }}$ の結果を示している. 何れの場合でも, iMMG は初期一定值を示した後, 増大する結果であった (cf. Fig. 2B: iMMG).

目標筋力の差異によって, Fig. 5Aは474秒で，Bは164 秒で観察対象MUの活動参加が見られた。活動参加時点 に差があっても, MU活動参加時点のiMUMSは初期值 に対して有意な高值を示す共通した傾向にあった。しか し，その後の一定相（活動参加相）に注目した時，Aで は480秒值に対して570秒值で有意な高值となったが，B では180秒值に対して450秒值で有意な高值となった，早 期の活動参加では活動参加相の一定期間が長い傾向にあ り，そののちに後半部増大相に移行した。164秒でMU活 動参加した場合（B）のiMUMSは，初期一定の前活動参 加相, 活動参加による増大とその後の一定相（活動参加 相), 後半部増大相の 3 相が明確であり, Fig. 2 に示した 結果と類似した傾向にあった。

iMES は初期一定值, その後に単調な増加傾向にあっ た。また, iMUAPは観察対象MUの活動参加により，有 意な高值となり，その後は一定值で推移した（Figs. 5 C \& D).

活動参加後のMUMS 原波形から加算平均して求めた MUMS波形の振幅（MS-V $\mathrm{V}_{\text {positive }}$ ) は, Fig. $5 \mathrm{~A}$ とBのそれ ぞれの $\mathrm{iMMG}, \mathrm{iMUMS}$ と類似した変化の推移を持つ傾向 にあった. PICC初期に活動参加した場合, MS $-V_{\text {positive }}$ に iMUMSの示した活動参加相と後半部増大相の 2 相が判別 できた。 これに対して, 後半部に活動参加した場合, 単 純な増加傾向にあった。

Fig. 6 に他の 4 被験者 (4MUs) から得られた MS- $V_{\text {positive }}$ の結果を示した．各MUで活動参加闇值張力, 目標筋力

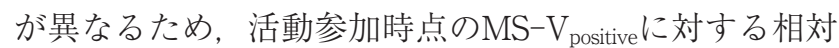
值で示している.PICC初期に活動参加した場合には一定 相を発現したが, 後半で活動参加した場合には短い一定 相も持って増加した。これらの傾向はFig. 5 に示した結 果と類似した。 


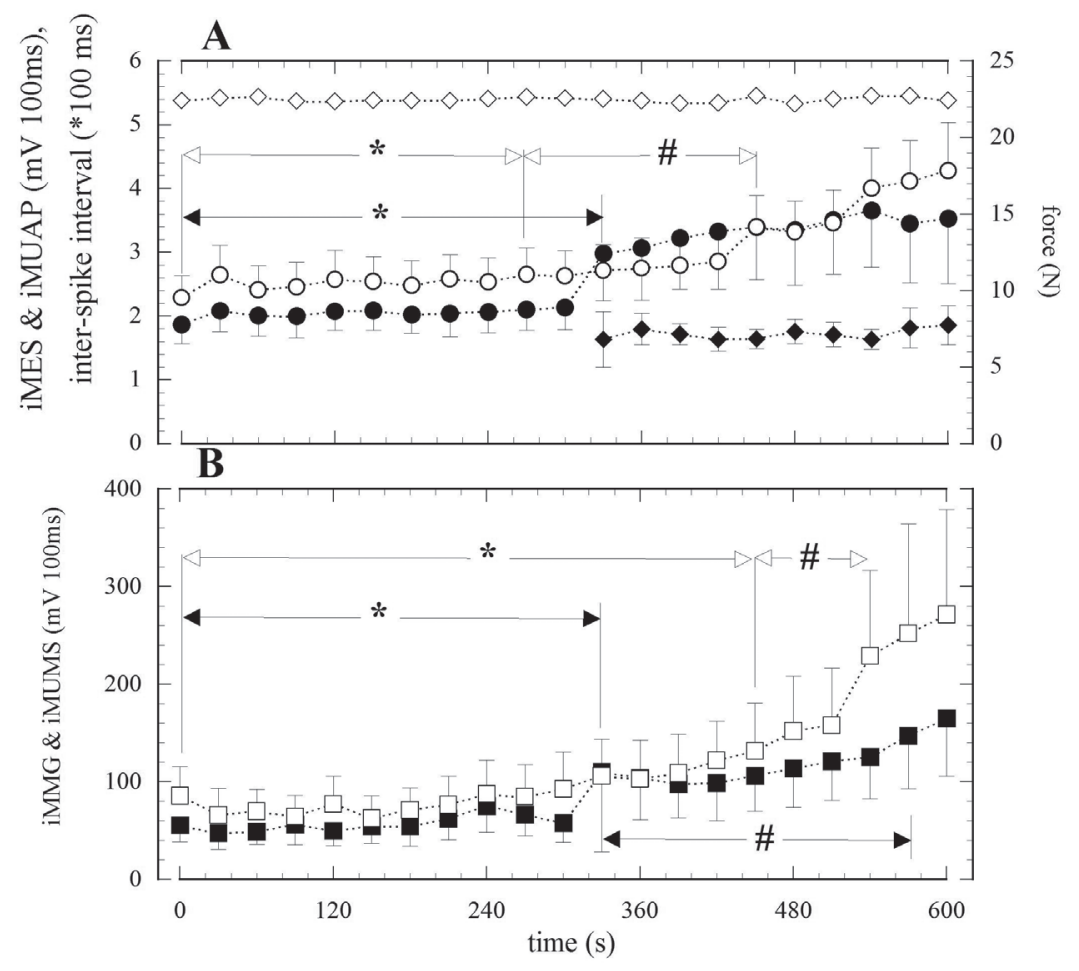

Fig. 2 Typical data of changes in integrated value of signals from $\mathrm{m}$. vastus lateralis (VL) during prolonged isometric constant contraction at $22.5 \mathrm{~N}(\mathrm{~A}: \diamond)$ for $10 \mathrm{~min}$. The recruitment threshold force of the objective MU was $30.5 \mathrm{~N}$. A: integrated value of myoelectric signal (iMES: $\bigcirc$ ) and integrated value of motor unit action potential (iMUAP: during the PICC. The objective MU recruited at $331 \mathrm{~s}$. IMUAP until recruitment of the objective MU means iMES from the back ground activity of MUs (MUAPs). Closed lozenge showed the change of inter-spike interval time $(\times 100 \mathrm{~ms})$ of the MU.

B: integrated MMG (iMMG: $\square$ ) and integrated motor unit mechanical signal (iMUMS: $\mathbf{}$ ) during PICC. IMUMS in an initial phase means iMMG from the back ground activity of MUs.

“*” means the value significant difference with the initial value at $0 \mathrm{~s}(\mathrm{p} \leqq 0.05)$ and "\#” indicates the value becoming larger significantly than the value at significant increment with the initial value. Filled/open arrow heads differentiated the indicated the value with filled/open symbols, respectively. Symbol and attached bar are mean value and standard deviation.

\section{考 察}

本報告では, 低い発揮筋力 $\left.(\leqq 20 \% \mathrm{MVC})^{7}\right)$ でのPICC 中に扔いてMU活動から提唱されているiMMG増大因子 を検証するため, 因子の一つとしてMU活動参加に注目 し，単一MUから検討を行った，実験課題実施に先立ち 観察対象とするMUの表面電極装着位置を特定し，その 後MUの活動参加闇值張力以下に設定した目標筋力で PICCを行った。この方法から, 観察対象のMUはPICC の経過中に活動参加した.MUAP導出電極は観察対象 MUの活動参加までは背景活動するMUが構成する干渉 波形（MES）を導出することになる。観察対象MUの活 動参加はMUAPの発現から直接確認が可能であり, 背 景活動にMUAPが重畳した信号となる。また, MUMS の活動参加はMUAPと同期した波形から確認できた。 さらに, MUMS発現は背景活動MMG波形に重畳するこ とから MMG波形 (iMMG) へのMU活動参加の影響が観 察可能であった (cf. Figs. 2 \& 3: inset).
MU活動参加とiMUMS, iMMG PICC経過中, MUの活 動参加によりMMGにMUMSが重畳し, iMUMSは参加 前值に比して有意な高值を示し, 後半部増大相に至るま でその值を一定保持した (Figs. 2B \& 5 : 活動参加相).

MU活動参加時点とその前後の iMUMS を詳細に検討 したところ, Figs. 3 \& 4 insetに示したように活動参加 後MUMS振幅の減少があり，iMUMSはその減少に依存 した漸減傾向にあった。AMG（acoustomyogram）の振 幅は電気刺激頻度に反比例すること ${ }^{1,2}$, また随意的筋力 発揮時のMUMS振幅（MS- $V_{\text {positive }}$ ) では放電頻度に反比 例する ${ }^{3}$ 特徵が短時間の実験試技 $\left(4 \sim 6\right.$ 秒 ${ }^{1,2)}, \quad 10$ 秒 $\left.{ }^{3}\right)$ の際に発現する。従って, 活動参加後のMUの連続放電 の影響によるMUMS振幅減少とその結果のIMUMSの変 化動態と考えられる。活動参加時点のiMUMS増大が他 のMUに拈いても観察することが出来た（Fig. 4). PICC 中のMU活動参加はその時点の $\mathrm{iMMG}$ を増大することが 示された。 

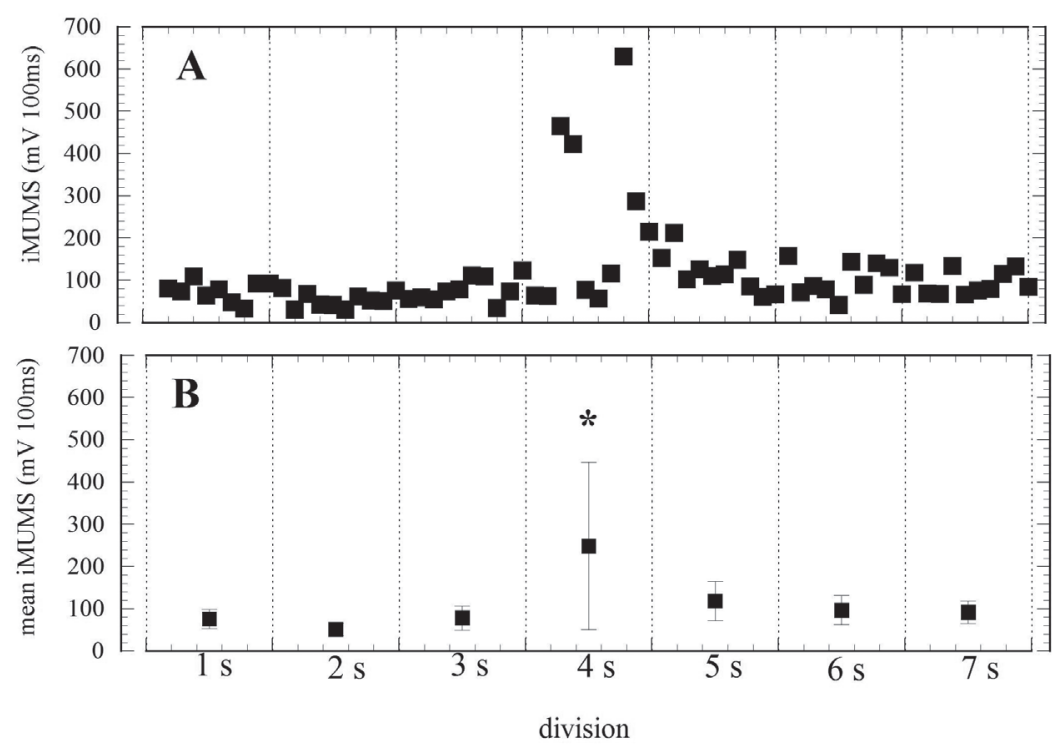

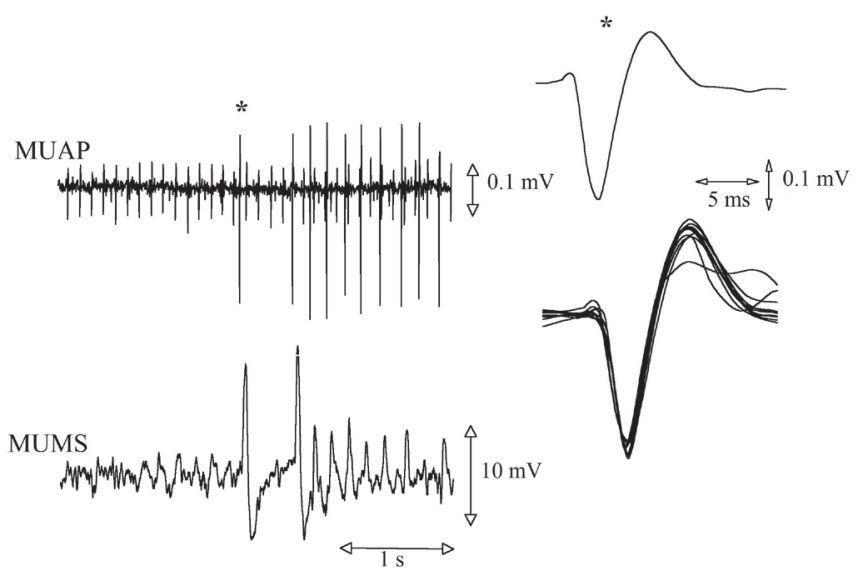

Fig. 3B での観察対象 MUの活動参加前 iMUMS 值 ( 1 - 3 division）と参加後值（ $5-7$ division）には有意差 が見られなかったが，Fig. 4Bの後值は前值に比較し有 意な高值となった。 Fig. 4 のMU活動参加時点は474秒で $\mathrm{iMMG}$ の後半部増大相にあった。活動参加相または後半 部増大相の違いによるMUMS振幅の放電間隔依存性に 差異 ${ }^{3)}$ を生じるか, 活動参加時点に依存した他の増大因 子が存在するか，等の観点から検討する必要がある。

iMMGに関して, Fig. 2Bと Figs. 5A \& B の結果はこ れまでの報告にあるPICC時のiMMGの変化動態3,9) と一 致しており，低い目標筋力では初期から後半部増大相に 見られる有意な高值となる時点までは一定值にあった。 活動参加時点とその後のMUMS振幅（又はiMUMS）の 減少は比較的短時間での現象で，10秒の積分区間とした
Fig. 3 Inset: Raw wave form of MUAP and MUMS before and after the recruitment timing of the objective MU from VL muscle (sampling rate at $500 \mathrm{~Hz}$ ).

Bipolar MUAP wave form at recruitment timing, indicated by “*”, and the superimposed MUAP wave form for 10 spikes from the recruitment were shown at upper and lower in right column with enlargement of time scale and increment of sampling rate $(2 \mathrm{KHz})$.

A: iMUMS calculated on every $100 \mathrm{~ms}$ division of the MUMS signal through before (3s) and after ( $3 \mathrm{~s})$ the MU recruitment $(1 \mathrm{~s})$. In front of the recruitment division, iMUMS consisted from back ground activity of the MUs (MMG). From the just after the MU recruitment, iMUMS consisted from the back ground activities and MUMS itself.

B: mean value (and its standard deviation: attached vertical bar) of iMUMS for each $1 \mathrm{~s}$ division shown in A. IMUMS at $4 \mathrm{~s}$ division was corresponding with the recruitment timing. Comparison the iMUMS between the front and the behind the recruitment division, there was no significant difference. IMUMS at $4 \mathrm{~s}$ division (recruiting division) was significantly larger than other divisions.

Results in this figure extract from a part of data of the experimental trial shown in Fig. 2. "*" means a significant different at $\mathrm{p} \leqq 0.05$.

iMUMS平均值を統計上有意な増大を得るまでに至らな かったことも一因と考えられる。

Kamo \& Morimoto ${ }^{5)}$ は10\%MVC以下の目標筋力での 持続的一定筋力発揮時におけるMUの放電特性を観察し ている.この時, 持続的筋力発揮初期からMUの活動参 加, 活動MUの活動休止が発現することを内側広筋, 外 側広筋，大腿直筋で観察している ${ }^{6)}$ 。同一の被験筋，実 験条件下で実施した本実験試技時においてもMU活動参 加と活動休止の発現が考えられる。iMMGのPICC後半 部増大期に至るまでの等值期間はiMESも一定值をとっ た期間内にあったことから，この一定值期間の発現は MU活動参加と活動休止の平衡が関与している可能性が ある。

本実験条件のような低い目標筋力発揮では筋深層に 

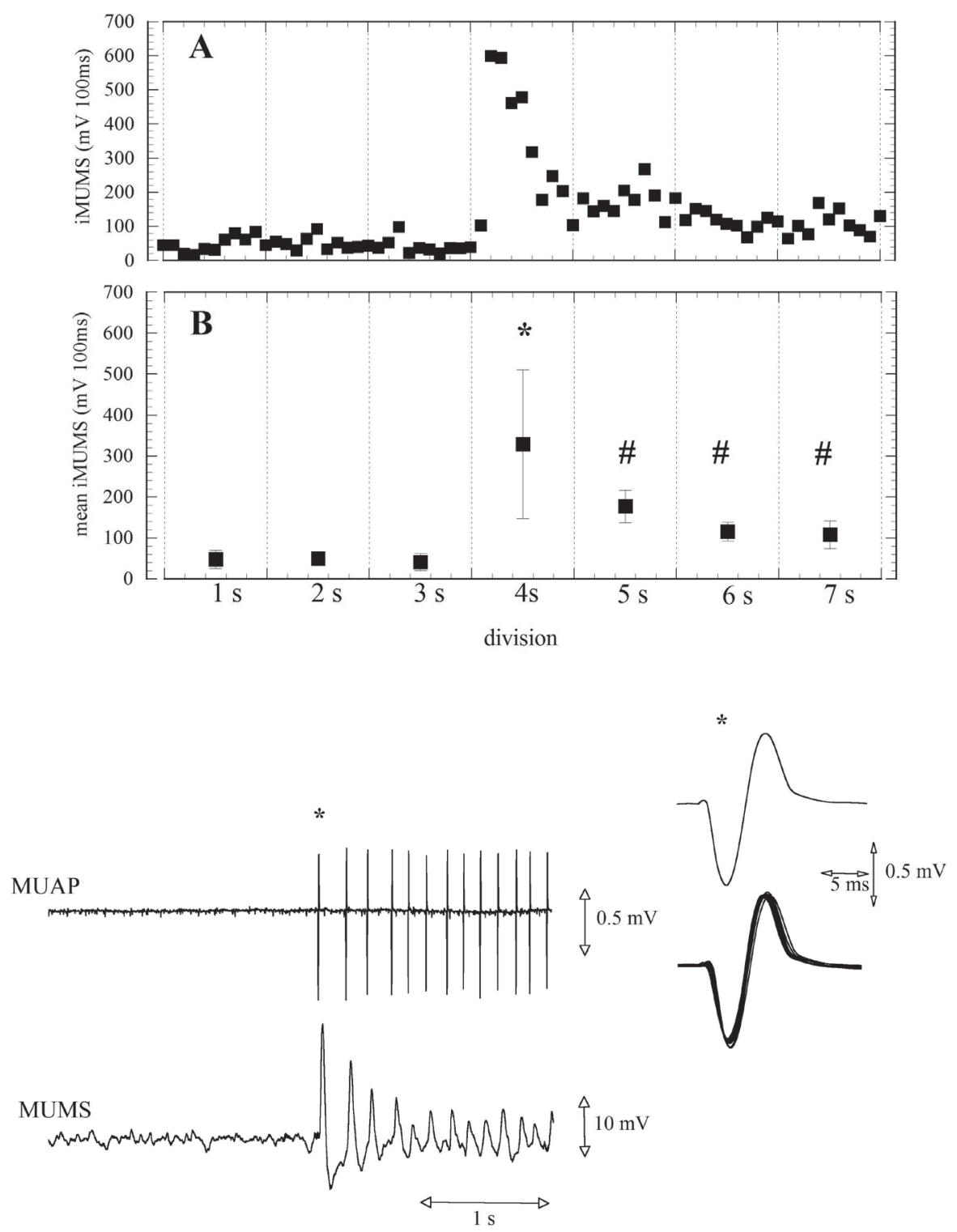

Fig. 4 Inset: Raw wave form of MUAP and MUMS before and after the recruitment timing of the objective MU (with the recruitment threshold force of $27 \mathrm{~N}$ ) from m. vastus medialis (VM) in the other subject with shown in Fig. 3. Bipolar MUAP wave form at recruitment timing, indicated by "*”, and the superimposed MUAP wave form for 10 spikes from the recruitment were shown at upper and lower in right column with enlargement of time scale and increment of sampling rate $(2 \mathrm{KHz})$.

Symbols in A and B shows the integrated value obtained from the same calculation methods as the methods in Figs. 3 A \& B.

“*” means a significant different among the divisions $(\mathrm{p} \leqq 0.05)$. "\#” indicates the significant difference between the values in front of the recruitment division and the behind divisions $(\mathrm{p} \leqq 0.05)$.

分布する遅筋型 $M U^{14,15)}$ の活動参加が主と考えられてい る. MUAP ${ }^{12)}, \mathrm{MUMS}^{16}$ 振幅は発生源から電極，セン サーまでの距離に依存した隇衰を呈する。筋深層部で活 動参加するMUのそれぞれの信号は筋表面で導出される MES，MMG振幅に大きな貢献を示さなくなることから も，本PICC時初期のiMES，iMMG一定值の出現の可能 性もある。本実験での表面導出MUは筋表層に分布し電

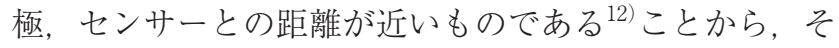
れぞれの信号は小さな減衰の下で導出され, iMUAP,
iMUMSに明確な増大が現れたと考えられる。

iMMG のPICC後半部増大相を構成する因子 観察対象 MU 活動参加後のiMUMS はiMMGの変化動態に類似し た（Figs. 5A \& B)。また，MUAPをトリガー信号とし た加算平均から求めたMUMS 波形振幅 (MS- $\left.\mathrm{V}_{\text {positive }}\right)$ も iMMG，iMUMS と類似した変化動態を示した。

$M S-V_{\text {positive }}$ の後半部増大の発現を $M U$ 活動参加時点の 差異から検討した時，増大期に至るまでのMUの放電期 

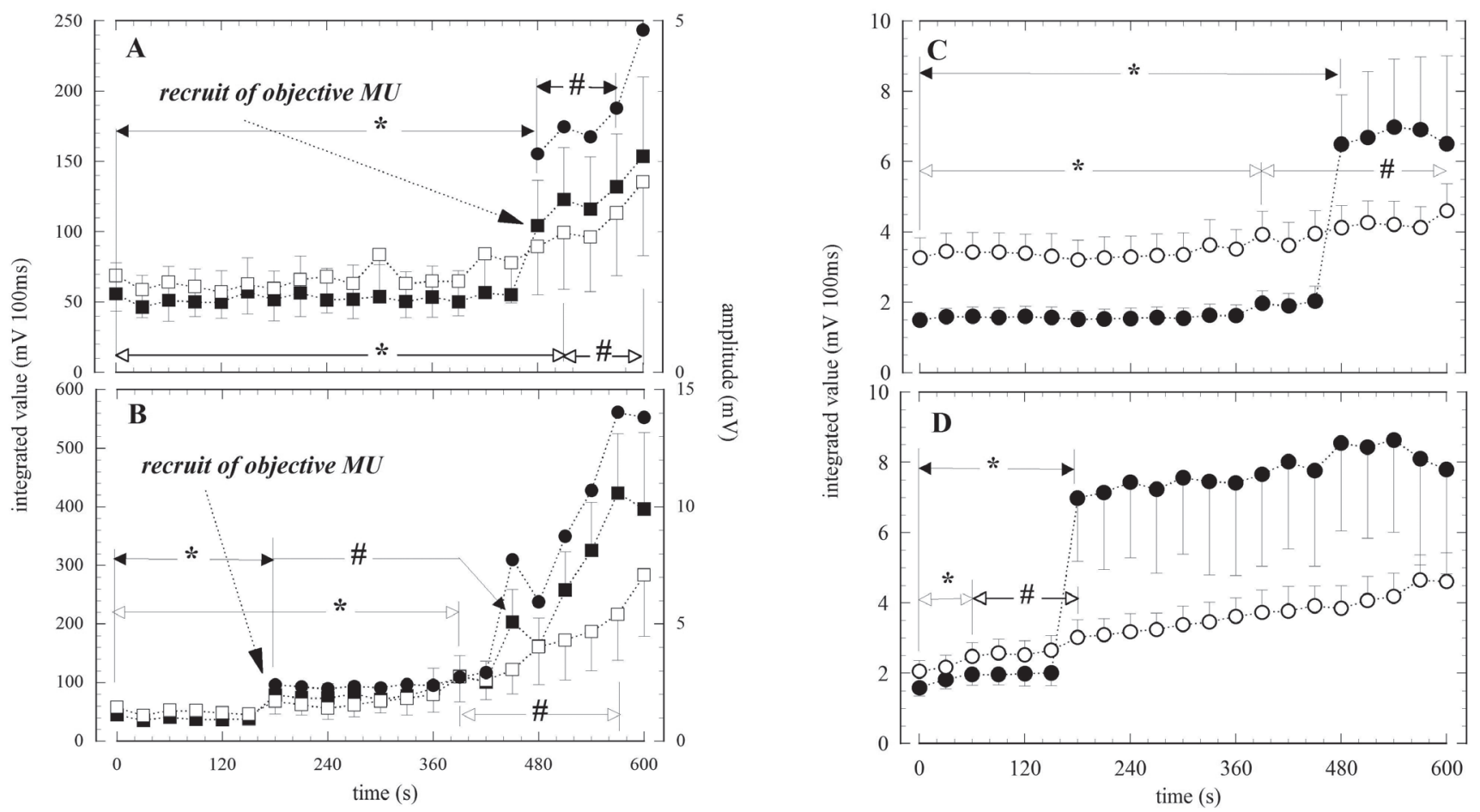

Fig. 5 Different development of $M S-V_{\text {positive }}$ depended on the recruitment timing, at iMMG constant phase or at iMMG increment phase, during the PICC. For the single MU from VM muscle with the recruitment threshold force of $27 \mathrm{~N}$, the target force was set at $22 \mathrm{~N}(\mathrm{~A} \& \mathrm{C})$ and $25 \mathrm{~N}$ (B \& D) in order to recruit the different timing during the PICCs.

A: the objective MU recruited at 474 s during the PICC. IMMG ( $\square)$, iMUMS (ם) and MS-V positive $(\mathbf{\bullet})$ during the PICC at 22 N. B: iMMG ( $\square$ ), iMUMS (ם) and MS- $\mathrm{V}_{\text {positive }}(\mathbf{\bullet})$ during the PICC at $25 \mathrm{~N}$. In this experimental trial, the objective MU recruited at $164 \mathrm{~s}$ of the PICC.

C \& D: iMES $(\bigcirc)$ and iMUMS $(-)$ during the PICC at $22 \mathrm{~N}$ and $25 \mathrm{~N}$ target force, respectively. Signals shown in C and D simultaneously recorded with the signals representing in A and B, respectively.

"*" means the value significant difference with the initial value at $0 \mathrm{~s}(\mathrm{p} \leqq 0.05)$ and "\#" indicates the value becoming larger significantly than the value at significant increment with the initial value ( $\mathrm{p} \leqq 0.05)$. Filled/open arrow heads differentiated the indicated value with filled/open symbols.

間（活動期間）の長さに影響されない結果を得た（Figs. $5 \mathrm{~A} \& \mathrm{~B})$. 活動参加後のiMUMSに内在する背景活動 MUの積分值をiMMGの変化動態に代用した時, MUの 活動参加がPICC中の便宜的に分けたiMMGの一定相, 後半の増大相の何時に発現するかに依存したMS- $V_{\text {positive }}$ 変化動態にあると考えられる。

時系列デー夕に増大発現時間の一致が見られないが, $\mathrm{iMMG}$ の PICC 後半部増大相は iMESの増大期にもあっ た (Fig. 2)。iMES増大にMUの活動参加が関与してい ることが推定でき, iMMGの増大が活動参加に起因する ことが期待される. iMMGの増加とMU活動参加直後に 放電間隔に依存したMUMS振幅と iMUMSが減少する事 （Figs. 3 \& 4）を考え合わせると, 後半部増大期には大 きなMUMS振幅として導出されるMUの順次, 連続した 活動参加が必要と考えられる (cf. Akataki et al.) $)^{4}$.

活動参加するMU数の増加により活動MU間での非特異 的同期化活動の確率が上昇することが考えられる ${ }^{17)}$. し かし, 観察対象MUと背景活動MUの同期化活動の程度と $M S-V_{\text {positive }}$ の間には意味ある関倸が見られなかった
た, MUMS波形は観察対象MUAPをトリガーとして加算 平均しているため, 観察対象MU以外のMU活動によっ て影響されない.ささらに, iMUAPは活動参加後一定值 をとったことから（Figs. 2 \& 5), iMUAPを増大するに は十分な活動増加が背景MUに無かったことが示唆され る. $M S-V_{\text {potive }}$ と iMUMSの後半部増大は観察対象以外の MUの活動参加に影響されない現象と考えられる。従っ て, MU活動参加数の増大によると仮定したiMMG増大 とMS- $\mathrm{V}_{\text {positive }}$ の後半部増大を同時に解釈することは困難 となる.MMGを構成する基本波形をMUMSとした時, $\mathrm{MS}-\mathrm{V}_{\text {positive }}$ 自体の増大がMMG（iMMG）増大に反映する ことの可能性も考えられる. 以上から，（1）iMMGの後 半部増大相は, 順次, 連続した大きな振幅のMUMSとし

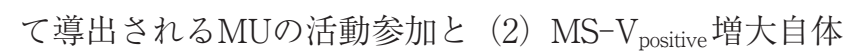
に起因した現象と考えられる。（1）の因子はMUAP導出 からの直接的な検討が必要と考えられる。

$\mathrm{PICC}$ 時の $\mathrm{MS}-\mathrm{V}_{\text {positive }}$ の増大は, 活動参加, 放電頻度変

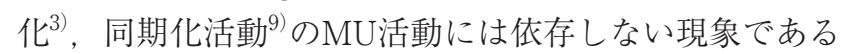
ことが示唆された. MUMSはMUAP（又は, 膜電位とし 


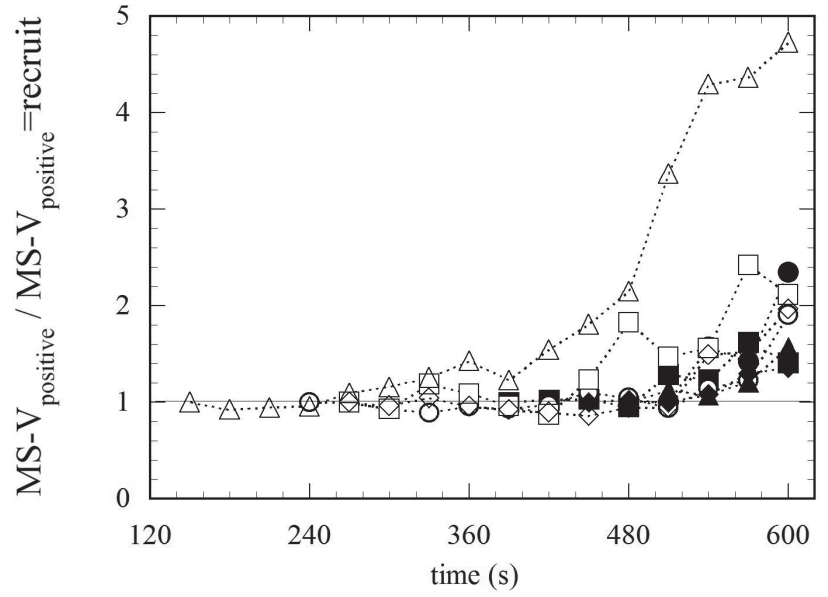

Fig. 6 MS-V $V_{\text {positive }}$ during PICC obtained from four MUs (four subjects). Each filled and open symbol corresponds to the same MU at two different target forces below the recruitment threshold, respectively. Open symbols means the experimental trial at the target torque just below the recruitment threshold of the objective MU for relatively early recruitment occurring. In contrast, filled symbols set the target torque low level enough to recruit the objective MU later part of the PICC. MS- $\mathrm{V}_{\text {positive }}$ shows in the relative value to an initial value (at recruiting timing)

てのaction potential）発現から興奮-収縮連関を経由した 筋線維 (群) のinternal shortening と internal stretching に起因した筋線維周囲径変化 [振動現象 (構造 ·形態変 化）上考えられ ${ }^{16)}$, 径変化自体および振動の伝導媒体

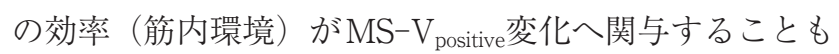
推定される.

活動参加するMU数の増加は筋内圧を上昇させる ${ }^{18)}$. さらに低い筋力発揮時に外部から骨格筋を加圧した時, MMG（MMG-RMS）に影響を及ぼさなかったことから 筋内圧上昇は振動信号伝導媒体の伝導性を上昇させると した報告がある ${ }^{19)}$ 。本実験結果においても，MU活動参 加数の増加が骨格筋内圧の上昇を来たし, 伝導媒体伝導 性変化がMMG波形, MUMS波形に影響したことが示唆 される。しかし，10\%MVCの持続的筋力発揮中に筋内 圧は変動しないとした報告もある20)ことから筋内圧の影 響のみに確定できない。

低強度の持続的筋力発揮時における $\mathrm{MS}-\mathrm{V}_{\text {positive }}$ および $\mathrm{iMMG}$ の後半部増大期へ関与する因子は現段階では未確 定である。しかし, MS- $V_{\text {positive }}$ とiMMGはPICC時の発揮 筋力に依存して後半部増大期が早期に発現する報告 ${ }^{9)}$, 本報告のMUの放電期間（活動期間）に依存しないMS-

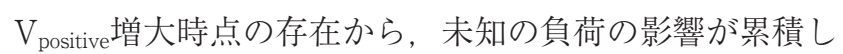
増大因子を発現させる “閾值” の存在の考え方も示唆さ れる。
低い目標筋力でのPICC時にiMMGは増大する。こ の増大因子をMUの活動参加から検討を加えた。内側 広筋または外側広筋を被験筋とし, 観察対象MUの活 動参加閾值張力以下の目標筋力を設定し, PICC中に MUの活動参加が発現するようにした. MES, MUAP, MMG，MUMSおよび発揮筋力を同時記録した。iMUAP と iMUMSは観察対象のMU活動参加までは背景活動 MUAP (MES), MUMS (MMG) の積分值を示し, MU の活動参加でMUAP, MUMSがMES, MMGに重畳した 信号積分值となった.

1 ） PICC時のiMMGは初期一定值，後半で増大する傾 向にあった。iMUMSは観察対象MUの活動参加で有意 な高值となり, PICC後期にはさらに増大した。

2) MU活動参加時点と前後 3 秒間のiMUMSを比較し た時, 活動参加時点は前後值に比較し有意に高值となっ た。しかし，観察したMUにより前值と後值間には有意 差が見られない場合もあった。これはMU活動参加直後 の持続した放電に依存したMUMS波形振幅の減少程度 に起因した現象であった。

3 ) MUAP で加算平均し求めた $M S-V_{\text {positive }}$ は $\mathrm{iMMG}$, iMUMSと類似した変化動態にあった。すなわち, iMMG 一定相に活動参加した場合, 後半部増大相まで一定值に あった。しかし, iMMG増大期に活動参加した時, 一定 相を有さず増大に推移した。

観察対象MUの活動参加閾值張力以下を目標筋力とし てのPICC時, PICC経過中にMUは活動参加し, 参加時 点のiMUMSは有意に増大した. PICC後半部のiMUMS 増大をMU活動参加数の増加から説明可能であったが, MUMSがMMGの構成基本波形とした時, $M S-V_{\text {positive 増 }}$ 大がiMMG増大に関与したことも推定された，MUの活 動状況のみならず, 筋内および筇線維 (群) に発現する 状態変化からMMG, MUMS波形の検討も必要と考える.

\section{謝 辞}

本研究は文部科学省科学研究費補助金（基盤研究 (C), 課題番号2150062700）の助成を受けて実施された.

\section{文献}

1) Stokes MJ \& Cooper RJ. Muscle sounds during voluntary and stimulated contractions of the human adductor pollicis muscle. J Appl Physiol 72: 1908-1913, 1992.

2) Yoshitake $Y$, Shinohara M, Ue H \& Moritani T. Characteristics of surface mechanomyogram are dependent on development of fusion of motor units in humans. $J$ Appl Physiol 93: 1744-1752, 2002.

3）森本 茂, 随意的筋力発揮時の単一運動単位筋振動信号 (筋音) 振幅の放電間隔依存性, 体力科学, 60：207-216, 2011. 
4) Akataki K, Mita K, Watanabe M and Itoh K. Mechanomyogram and force relationship during voluntary isometric ramp contractions of the biceps brachii muscle. Eur J Appl Physiol 84: 19-25, 2001.

5) Kamo M \& Morimoto S. Discharge properties of human motor units during sustained contraction at low level force. J Electromyog Kinesiol 11: 255-261, 2001.

6) Kamo M. Discharge behavior of motor units in knee extensors during the initial stage of constant-force isometric contraction at low force level. Eur J Appl Physiol 86: 375-381, 2002.

7) Orizio C, Perini R and Veicsteinas A. Changes of muscular sound during sustained isometric contraction up to exhaustion. J Appl Physiol 66: 1593-1598, 1989.

8) Goldenberg MS, Yack HJ, Cerny FJ and Burton H. Acoustic myography as indicator of force during sustained contractions of a small hand muscle. J Appl Physiol 70: 87-91, 1991.

9）森本 茂, 石渡千草, 宮本奈芳美, 加茂美冬：持続的筋力 発揮時の運動単位筋振動信号と運動単位の同期化活動, 体力科学, 58: 365-378, 2009.

10）森本 茂, 加茂美冬：単一運動単位の活動電位波形の表 面筋電位構成への貢献, 体力科学, 49: 157-170, 2000.

11) Morimoto S, Gotoh $\mathrm{H}$ and Kamo M. Conducted and non-conducted components in spike potentials of human single motor units. J Physiol Soc Japan 50: 477, 1988.

12) Morimoto S, Umazume $Y$ \& Masuda M. Properties of spike potentials detected by a surface electrode in intact human muscle. Jap J Physiol 30: 71-80, 1980.

13) Morimoto S. Effect of length change in muscle fibers on conduction velocity in human motor units. Jap $J$ Physiol 36: 773-782, 1986.

14) Clamann HP. Activity of single motor units during isometric tension. Neurology 20: 256-260, 1970.

15) Burk RE. Motor unit: anatomy, physiology and functional organization. In: Handbook of Physiology. The Nervous System. Motor control, Bethesda, MD: Am Physiological Soc, sect. 1, vol. II, part 1, chapt. 10, p. 345-422, 1981.

16) Morimoto $S$ and Takemori $S$. Initial mechanomyographycal signals from twitching fibres of human skeletal muscle. Acta Physiol 191: 319-327, 2007.

17) Halliday DM, Conway BA, Farmer SF \& Rosenberg JR. Load-independent contributions from motor unit synchronization to human physiological tremor. Neurophysiol 82: 664-675, 1999.

18) Sadamoto T, Bonde-Peterson F \& Suzuki Y. Skeletal muscle tension, flow, pressure, and EMG during sustained isometric contractions in humans. Eur J Appl Physiol 51: 395-408, 1983.

19) Søgaard C, Orizio C \& Sjøgaard G. Surface mechanomyogram amplitude is not attenuated by intramuscular pressure. Eur J Appl Physiol 96: 178-184, 2006.

20) Blangsted AK, Vedsted P, Sjøgaard G \& Søgaard K. Intramuscular pressure and tissue oxygenation during low-force static contraction do not underlie muscle fatigue. Acta Physiol Scand 183: 379-388, 2005. 